\title{
OPTIMIZATION OF THE LINING WEAR COEFFICIENT ON THE BASIS OF CONTROL OF THREE-PHASE CURRENT ELECTRIC ARCS CHARACTERISTICS
}

\author{
O.V. Loginovskiy ${ }^{1}$, loginovskiyo@mail.ru, \\ E.M. Kostyleva ${ }^{1}$, ezaretskaya@yandex.ru, \\ I.M. Yachikov², jachickov@mail.ru \\ ${ }^{1}$ South Ural State University, Chelyabinsk, Russian Federation, \\ ${ }^{2}$ Nosov Magnitogorsk State Technical University, Magnitogorsk, Russian Federation
}

Introduction. Currently, the most important task of the steel industry is to constantly update the product range, increase its operational characteristics, and increase the efficiency of equipment use. Achieving goals is possible with a methodological base based on the principles of system analysis.

In metallurgy, multi-electrode arc furnaces using three-phase alternating current are widely used. The lining layer present in such units during operation is subjected to thermal and electromagnetic effects created by the arc. A quantitative measure of this effect is the lining wear coefficient (LWC). In most studies, the influence of the described factors on the LWC is not taken into account. At the same time, heat fluxes affecting all elements of the furnace structure, including the lining, depend on the shape of the arc.

Aim. Selecting the parameters of the electric arc furnace, which optimizes the lining wear coefficient.

Materials and methods. When performing the work, methods of computational mathematics and evolutionary methods of numerical optimization of functions of many variables were used. Software which uses freely distributed scientific libraries was based on them.

Results. The influence of the system of three burning arcs on the wear coefficient of the lining is considered taking into account the shape of the axis of the arc column.

Conclusion. An algorithm and program have been elaborated that allow us to evaluate the thermal perception of the lining depending on the shape of the arcs. Based on the developed algorithm, special software can be created that is integrated into the system of automated regulation and prediction of the thermal operation of multi-electrode arc units to increase the reliability of assessing the wear of the furnace lining under different technological modes of arc burning.

Keywords: electric arc, multi-electrode arc furnace, three-phase alternating current, electromagnetic interaction, arc post axis shape, lining wear coefficient, evolutionary algorithms.

\section{Introduction}

The problems of increasing the efficiency of industrial enterprises are now becoming increasingly relevant $[1,2]$, while the task of optimizing the activity of industrial units and machines is of particular importance. There are a large number of industrial units, the basis of which is the use of energy created by an electric arc. The lining layer present in such units during operation is subjected to thermal and electromagnetic effects created by the arc. A quantitative measure of this effect is the lining wear coefficient (LWC), one of the most important technological characteristics of modern multi-electrode arc furnaces. The most significant effect on the LWC is exerted by the arc power, the distance from the arc axis to the lining, and the applied voltage. In most studies, the influence of the described factors on the LWC is not taken into account. At the same time, heat fluxes affecting all elements of the furnace structure, including the lining, depend on the shape of the arc.

The aim of the work is to study this effect and find the parameters that provide optimization of the LWC. To achieve this goal, an algorithm for calculating the shape of arcs in an AC steelmaking furnace has been developed, which will be used to optimize the objective function.

Analysis of the shape of alternating current electric arcs parallel burning

in the direction of the horizontal surface during their electromagnetic

interaction and the influence of this shape on the lining wear coefficient

The electromagnetic interaction of the arcs is determined by the equilibrium equation of the arc column element [3-6] 


$$
d \vec{F}_{1-2}+d \vec{F}_{1-1}+d \vec{F}_{1-u}=0,
$$

where $d \vec{F}_{1-2}$ is the force of interaction of an arc element with another arc (or other arcs), $d \vec{F}_{1-1}$ is the force of interaction of an arc element with itself, $d \vec{F}_{1-u}$ is centrifugal force seeking to straighten an arc column.

Electromagnetic interaction of three arcs through which harmonic currents with phase shift flow $2 \pi / 3: i_{1}=i_{01} \sin \frac{2 \pi}{T} \tau, i_{2}=i_{02} \sin \left(\frac{2 \pi}{T} \tau+\frac{2 \pi}{3}\right)$ и $i_{3}=i_{03} \sin \left(\frac{2 \pi}{T} \tau-\frac{2 \pi}{3}\right)$, where $i_{01}, i_{02}, i_{03}$ are amplitude values of currents [4]. Consider the case when the current value of the currents is the same $i_{\partial 1}=i_{\partial 2}=i_{\partial 3}=i_{\partial}$.

In the electromagnetic interaction of three alternating currents, two repulsive forces act on the element $d \vec{l}_{1}: d F_{1-2}=\chi \cdot i_{1} i_{2} d l_{1}, d F_{1-3}=\chi \cdot i_{1} i_{3} d l_{1}$. Direction of the resulting force $d \vec{F}_{1-2-3}$ changes over time and coincides at any time with the vector $d \vec{F}_{1-2}+d \vec{F}_{1-3}$. The modulus of the resulting force is equal to

$$
d F_{1-2-3}=\sqrt{3} d F_{1-2}=\sqrt{3} F_{0}\left|\sin \frac{2 \pi}{T} \tau\right| \cdot d l_{1},
$$

where $F_{0}=\frac{\chi \cdot i_{\partial}^{2}}{2}$.

Since the instantaneous strength values $d F_{1-2-3}$ are continuously changing during each half-cycle, the electrodynamic forces acting on the arc element change in magnitude and direction. We find the average integral force over half a period that determines the average position of the arc

$$
d \tilde{F}_{1-2-3}=-\frac{2 i_{\partial}^{2}}{T} \cdot \frac{\chi \sqrt{3}}{2} \int_{0}^{\frac{T}{2}} \sin \left(\frac{2 \pi}{\mathrm{T}} \tau\right) d \tau \cdot d l_{1}=-\frac{\sqrt{3}}{\pi} i_{\partial}^{2} \cdot d l_{1} \approx-0,551 \cdot i_{\partial}^{2} \cdot d l_{1} .
$$

This force is directed from the center of decay of the electrodes.

Consider the electromagnetic interaction of an arc element $d \vec{l}_{1}$ and direct current from the side of the arc. Vector $d \vec{F}_{1-1}$ is in the plane $y O z$, is perpendicular to $d \vec{l}_{1}$ and oppositely directed to the vector $d \vec{F}_{1-2}$, and its module [4]

$$
\left|d \vec{F}_{1-1}\right|=\frac{\mu_{0} I_{1}^{2}}{4 \pi} \int_{0}^{l} \frac{\left(\frac{d y(\zeta)}{d \zeta}(\zeta-z)-(y(\zeta)-y(z))\right)}{r_{31}^{3}} d \zeta \cdot d l_{1}=\chi_{1} I_{1}^{2} \cdot d l_{1} .
$$

In the electromagnetic interaction of a harmonic current $i_{1}=i_{01} \sin \left(\frac{2 \pi}{T} \tau+\phi\right)$ with itself average integral value of force

$$
d F_{1-1}=\frac{\chi_{1}}{T} \int_{0}^{T} i_{1}^{2} d \tau=\frac{\chi_{1} i_{01}^{2}}{T} \int_{0}^{T}\left(\sin \frac{2 \pi}{T} \tau+\phi\right)^{2} d \tau \cdot d l_{1}=\frac{\chi_{1} i_{01}^{2}}{2} \cdot d l_{1}=\chi_{1} i_{\partial 1}^{2} \cdot d l_{1} .
$$

It is seen that the electromagnetic interaction of direct current with itself is the same as an alternating current with the same effective value.

In the general case, equation (1) of the equilibrium of an element of an arc column during its electromagnetic interaction with one or two arcs of constant or alternating currents can be written as

$$
k_{1} d \vec{F}_{1-2}+d \vec{F}_{1-1}+d \vec{F}_{1-u}=0 .
$$

Based on the algorithms proposed in [3, 4, 6-12], one can solve equation (5) and obtain an approximate description of the shape of the arc.

The most important indicator of the thermal load of the furnace lining is the lining wear coefficient (LWC) [13-15]. LWC is defined as $L W C=\frac{3 P_{d} U_{d}}{a^{2}}$, where $P_{d}$ is the arc power, $U_{d}$ is the arc voltage, $a$ is a distance from the arc axis to the lining [13-15]. 
To more accurately determine the heat perception of the side wall, we modify the LWC calculation formula taking into account the shape of the axis of the arc column found when solving equation (5). To do this, we will find the LWC at the minimum distance from the wall from the arc. From physical considerations, we can conclude that the minimum distance from the arc to the lining is achieved at the point of contact of the arc with the surface of the melt. Based on this, it is possible to formulate a control problem for finding the optimal coefficient of wear of the lining, changing within acceptable limits the parameters that determine the operation of the furnace. As such parameters, the applied voltage and the distance from the surface of the melt to the end of the electrode can act, which can be adjusted during each stage of the process. To solve the problem of optimizing the LWC value, we use an approximately determined dependence of the shape of the arc on the control parameters. Since this dependence cannot be described analytically, the use of gradient optimization methods seems inappropriate. Therefore, for optimization, evolutionary methods are used.

For optimization, a genetic algorithm was chosen [16] with a population size of 17 individuals, a simple single-point crossover, a mutation with a probability of 0.2 was implemented. The software implementation is done using freely distributed Python packages. It was found that at currents of about $50 \mathrm{kA}$ and arc powers of about $20 \mathrm{MW}$, the lining wear coefficient varies from 1630 to $1750 \mathrm{MW} \cdot \mathrm{V} / \mathrm{m}^{2}$.

\section{Conclusions}

Based on the shape of the arcs, algorithmic and software have been developed to optimize the wear coefficient of the lining from three arcs of three-phase alternating current burning in the direction of a horizontal surface, make decisions on the effective heat transfer of the radiation of the arcs to the charge, depending on the shape of the arcs, determined by the power and voltage of the arc, the distance from the arc to the axis of the electrode.

\section{References}

1. Loginovskiy O.V., Maksimov A.A., Burkov V.N., Burkova I.V. Gelrud Ya.D., Korennaya K.A., Shestakov A.L. Upravlenie promyshlennymi predpriyatiyami: strategii, mekhanizmy, sistemy: monografiya [Management of Industrial Enterprises: Strategies, Mechanisms, Systems: Monograph]. Moscow, INFRA-M, 2018. 410 p.

2. Loginovskiy O.V., Gollai A.V., Dranko O.I., Shestakov A.L., Shinkarev A.A. Effectivnoe upravlenie organizacionnymi i proizvodstvennymi structurami [Effective Management of Organizational and Production Structures: Monograph]. Moscow, INFRA-M, 2020. 450 p.

3. Yachikov I.M., Kostyleva E.M. [The Mathematical Modeling of Form of Arcs with their Electromagnetic Coupling. Report 1]. Izvestiya Ferrous Metallurgy, 2014, vol. 57(1), pp. 59-64. (in Russ.)

4. Yachikov I.M., Kostyleva E.M. [The Mathematical Modeling of Form of Arcs with their Electromagnetic Coupling. Report 2]. Izvestiya Ferrous Metallurgy, 2014, vol. 57(5), pp. 56-61. (in Russ.)

5. Bortnichuk N.I., Krutianskii M.M. Plazmenno-dugovye plavilnye pechi [Plasma-Arc Melting Furnaces]. Moscow, Energoatomizdat, 1981. 120 p

6. Yachikov I.M., Kostyleva E.M. Modelirovanie formy dug postoyannogo toka pri ih elektromagnitnom vzaimodeistvii [Modeling the Shape of DC Arcs During their Electromagnetic Interaction]. Interregional Collection of Scientific Papers. Magnitogorsk, Publishing House of Magnitogorsk State Technical University, 2011, pp. 195-201. (in Russ.)

7. Azbelev N.V., Maksimov V.P., Rakhmatullina L.F. Elementy sovremennoi teorii funkcionalnodifferencialnyh uravnenii. Metody i prilozheniya [Elements of the Modern Theory of Functional-Differential Equations. Methods and Applications]. Moscow, Institute for Computer Research, 2002. 304 p.

8. Dmitriev S.S., Kuznecov E.B. [Numerical Solution of Systems of Integrodifferential-Algebraic Equations with Delayed Argument]. Computational Mathematics and Mathematical Physics, 2008, vol. 3, pp. 430-444. (in Russ.)

9. Verzhbickii V.M. Chislennye metody. Matematicheskii analiz i obyknovennye differencialnye uravneniya [Numerical Methods. Mathematical Analysis and Ordinary Differential Equations]. Moscow, Higher School, 2001. 383 p.

10. Yachikov I.M., Kostyleva E.M. [The Position of Electric Arcs during their Electromagnetic Interaction in Multi-Electrode Arc Furnaces]. Information Technologies and Systems: materials of the First Int. Conf. Chelyabinsk, Publishing House of Chelyabinsk State University, 2012. pp. 36-38. (in Russ.) 


\title{
Краткие сообщения
}

11. Yachikov I.M., Kostyleva E.M. [An Approximate Algorithm for Finding the Position of Electric Arcs during their Electromagnetic Interaction in Multi-Electrode Arc Furnaces]. Theory and practice of thermal processes in metallurgy: a collection of reports of an international scientific and practical conference. Ekaterinburg, Publishing House of Ural Federal University, 2012, pp. 423-426.(in Russ.)

12. Yachikov I.M., Kostyleva E.M. Vzaimodeistvie dug [Arcs Interaction] // Certificate of state registration of the program, 2013, no. 2013619388.

13. Sisoyan G.A. Elektricheskaya duga v elektricheskoi pechi [Electric Arc in an Electric Furnace]. Moscow, Metallurgy, 1971. 304p.

14 Egorov A.V. Raschet moshchnosti i parametrov elektroplavilnyh pechei [Calculation of Power and Parameters of Electric Melting Furnaces: Textbook for Universities]. Moscow, MISIS, 2000. 272 p.

15. Nikolayev A.A. Povyshenie effektivnosti raboty elektromehanicheskogo kompleksa "Dugovaya staleplavilnaya pech - staticheskii tiristornyi kompensator" [Improving the Efficiency of the Electrical Complex "Arc Steelmaking Furnace - Static Thyristor Compensator". Scientific monograph. Magnitogorsk, Publishing House of Nosov Magnitogorsk State Technical University, 2017.318 p

16. Emelianov V.V, Kureichik V.V., Kureichik V.M. Teoriya $i$ praktika evolucionnogo modelirovaniya [Theory and Practice of Evolutionary Modeling]. Moscow, FIZMATLIT, 2003. 432 p.

Received 2 June 2020

УДК 621.365.2:681:325

DOI: $10.14529 /$ ctcr200314

\section{ОПТИМИЗАЦИЯ КОЭФФИЦИЕНТА ИЗНОСА ФУТЕРОВКИ НА ОСНОВЕ УПРАВЛЕНИЯ ХАРАКТЕРИСТИКАМИ ЭЛЕКТРИЧЕСКИХ ДУГ ТРЕХФАЗНОГО ТОКА}

\author{
О.В. Логиновский ${ }^{1}$, Е.М. Костылева ${ }^{1}$, И.М. Ячиков ${ }^{2}$ \\ ${ }^{1}$ Южно-Уральский государственный университет, г. Челябинск, Россия, \\ ${ }^{2}$ Магнитогорский государственный технический университет им. Г.И. Носова, \\ г. Магнитогорск, Россия
}

Введение. В настоящее время важнейшей задачей черной металлургии является постоянное обновление сортамента продукции, повышение ее эксплуатационных характеристик, повышение эффективности использования оборудования. Достижение поставленных целей возможно при наличии методологической базы, основанной на принципах системного анализа.

В металлургии широкое распространение получили многоэлектродные дуговые печи с использованием трехфазного переменного тока. Имеющийся в таких агрегатах слой футеровки в процессе функционирования подвергается тепловому и электромагнитному воздействию, создаваемому дугой. Количественной мерой данного влияния является коэффициент износа футеровки (КИФ). В большинстве исследований влияния описанных факторов на КИФ форма дуги не учитывается. В то же время от формы дуги зависят тепловые потоки, воздействующие на все элементы конструкции печи, и в том числе на футеровку.

Цель исследования. Выбор параметров работы электродуговой печи, обеспечивающий оптимизацию коэффициента износа футеровки.

Материалы и методы. При выполнении работы применялись методы вычислительной математики и эволюционные методы численной оптимизации функций многих переменных. На них основывалось созданное с использованием свободно распространяемых библиотек программное обеспечение. Результаты. Рассмотрено влияние системы трех горящих дуг на коэффициент износа футеровки с учетом формы оси столба дуги.

Заключение. Создан алгоритм и программа, позволяющие оценивать тепловосприятие футеровки в зависимости от формы дуг. На основе разработанного алгоритма может быть создано 
специальное программное обеспечение, встроенное в систему автоматизированного регулирования и прогнозирования тепловой работы многоэлектродных дуговых агрегатов, для повышения достоверности оценки износа футеровки печи при разных технологических режимах горения дуг.

Ключевые слова: электрическая дуга, многоэлектродная дуговая печь, трехфазный переменный ток, электромагнитное взаимодействие, форма оси столба дуги, коэффициент износа футеровки, эволюичионнье алгоритмы.

\section{Лuтература}

1. Логиновский, О.В. Управление промышленными предприятиями: стратегии, механизмы, системь: монография / О.В. Логиновский, А.А. Максимов, В.Н. Бурков и др. - М.: ИНФРА-М, 2018. $-410 c$.

2. Логиновский, О.В. Эффективное управление организационными и производственными структурами: монография / О.В. Логиновский, А.В. Голлай, О.И. Дранко и др.; под ред. О.В. Логиновского. - М.: ИНФРА-М, 2020. - 450 с.

3. Ячиков, И.М. Математическое моделирование формы дуг при их электромагнитном взаимодействии. Сообщение 1 / Ячиков И.М., Костылева Е.М. // Известия вузов. Черная металлургия. - 2014. - 57(1). - С. 59-64.

4. Ячиков, И.М. Математическое моделирование формы дуг при их электромагнитном взаимодействии. Сообщение 2 / Ячиков И.М., Костылева Е.М. // Известия вузов. Черная металлургия. $-2014 .-57(5)$. - C. 56-61

5. Бортничук, Н.И. Плазменно-дуговые плавильные печи. / Н.И. Бортничук, М.М. Крутянский. - М.: Энергоиздат, 1981. - 120 с.

6. Ячиков, И.М. Моделирование формы дуг постоянного тока при их электромагнитном взаимодействии: межрегион. сб. науч. тр. / И.М. Ячиков, Е.М. Костылева; под ред. В.М. Колокольцева. - Магнитогорск: Изд-во Магнитогорск. гос. техн. ун-та. - Bыn. 11. C. $195-201$.

7. Азбелев, Н.В. Элементы современной теории функиионально-дифференциальных уравнений. Методы и приложения / Н.В. Азбелев, В.П. Максимов, Л.Ф. Рахматуллина. - М.: Институт компьютерных исследований, 2002. - 304 c.

8. Дмитриев, С.С. Численное решение систем интегродифференциально-алгебраических уравнений с запаздывающим аргументом / С.С. Дмитриев, Е.Б. Кузнецов // Журнал вычислительной математики и математической физики. - 2008. - 3. - C. 430-444.

9. Вержбичкий, В.М. Численные методы. Математический анализ и обыкновенные дифференииальные уравнения / В.М. Вержбиџкий. - М.: Высш. ик., 2001. - 383 с.

10. Ячиков, И.М. Положение электрических дуг при их электромагнитном взаимодействии в многоэлектродных дуговых печах / И.М. Ячиков, Е.М. Костылева // Информационные технологии и системы: материалы Первой междунар. конф. - Челябинск: Изд-во Челяб. гос. ун-та, 2012. C. 36-38.

11. Ячиков, И.М. Приближенный алгоритм нахождения положения электрических дуг при их электромагнитном взаимодействии в многоэлектродных дуговых печах / И.М. Ячиков, Е.М. Костылева // Теория и практика тепловых проиессов в металлургии: сборник докладов международной научно-практической конференции. - Екатеринбург: УрФУ, 2012. - С. 423-426.

12. Ячиков, И.М. Взаимодействие дуг / И.М. Ячиков, Е.М. Костьлева // Свидетельство о государственной регистрации программы № 2013619388 от 03 октября 2013.

13. Сисоян, Г.А. Электрическая дуга в электрической печи / Г.А. Сисоян. - М.: Металлургия, 1971. $-304 \mathrm{c}$.

14. Егоров, А.В. Расчет мощности и параметров электроплавильных печей: учеб пособие для вузов / А.В. Егоров. - М.: МИСИС, 2000. - 272 с.

15. Николаев, А.А. Повышение эффективности работы электротехнического комплекса «Дуговая сталеплавильная печь - статический тиристорный компенсатор»: научная монография / А.А. Николаев. - Магнитогорск: Изд-во Магнитогорск. гос. ун-та им. Г.И. Носова, 2017. $318 \mathrm{c}$. 


\section{Краткие сообщения}

16. Емельянов, В.В. Теория и практика эволючионного моделирования / В.В. Емельянов, В.В. Курейчик, В.М. Курейчик. - М.: ФИЗМАТЛИТ, 2003. - 432 c.

Логиновский Олег Витальевич, д-р техн. наук, профессор, заведующий кафедрой информационно-аналитического обеспечения управления в социальных и экономических системах, Южно-Уральский государственный университет, г. Челябинск; loginovskiyo@mail.ru.

Костылева Елизавета Марковна, соискатель, кафедра информационно-аналитического обеспечения управления в социальных и экономических системах, Южно-Уральский государственный университет, г. Челябинск; ezaretskaya@yandex.ru.

Ячиков Игорь Михайлович, д-р техн. наук, профессор, кафедра вычислительной техники и программирования, Магнитогорский государственный технический университет им. Г.И. Носова, г. Магнитогорск; jachickov@mail.ru.

Поступила в редакцию 2 июня 2020 г.

\section{ОБРАЗЕЦ ЦИТИРОВАНИЯ}

Loginovskiy, O.V. Optimization of the Lining Wear Coefficient on the Basis of Control of Three-phase Current Electric Arcs Characteristics / O.V. Loginovskiy, E.M. Kostyleva, I.M. Yachikov // Вестник ЮУрГУ. Серия «Компьютерные технологии, управление, радиоэлектроника». - 2020. - Т. 20, № 3. - С. 129-134. DOI: $10.14529 /$ ctcr200314

\section{FOR CITATION}

Loginovskiy O.V., Kostyleva E.M., Yachikov I.M. Coefficient on the Basis of Control of Three-phase Current Electric Arcs Characteristics. Bulletin of the South Ural State University. Ser. Computer Technologies, Automatic Control, Radio Electronics, 2020, vol. 20, no. 3, pp. 129-134. DOI: $10.14529 /$ ctcr200314 